Citation: Valerio-Cárdenas, C., Martínez-Herrera, J., VelázquezVargas, D. L., \& De la Cruz-Burelo, P. (2021). Determination of the point of zero charge of pineapple (Ananas comosus L.) peel and its application as copper adsorbent. Agro Productividad. https://doi.org/10.32854/agrop. v14il 1.2009

Editor in Chief: Dr. Jorge Cadena Iñiguez

Received: March 13, 2021. Accepted: October 6, 2021. Published on-line: November 26, 2021 .

This work is licensed under a Creative Commons Attribution-NonCommercial 4.0 International license.

\section{Determination of the point of zero charge of pineapple (Ananas comosus L.) peel and its application as copper adsorbent}

\author{
Valerio-Cárdenas, Cintya ${ }^{1}$; Martínez-Herrera, Jorge ${ }^{2}$; Velázquez-Vargas, Diana Laura ${ }^{1}$; \\ De la Cruz-Burelo, Patricia ${ }^{1}$ \\ 1 Universidad Popular de la Chontalpa. Carretera Cárdenas-Huimanguillo Km 2, Ranchería Paso y Playa, \\ 86597, Cárdenas, Tabasco, México. \\ 2 INIFAP-Campo Experimental Huimanguillo, Carretera Cárdenas-Huimanguillo, Km 1, 86400 Cárdenas, \\ Tabasco, México. \\ * Correspondence: cintya.valerio@upch.mx
}

\begin{abstract}
Objective: To determine the optimum $\mathrm{pH}$ at which the pineapple peel can adsorb the greatest amount of copper.

Design/methodology/approach: Sorbent material. The size of the pineapple peel was reduced to $0.250 \mathrm{~mm}$; it was chemically modified with $0.2 \mathrm{M} \mathrm{NaOH}$ and $0.2 \mathrm{M} \mathrm{CaCl}_{2}$. Point of zero charge (PZC). Six solutions were prepared with $0.5 \mathrm{~g}$ of sorbent in an aqueous medium (with a 3-8 $\mathrm{pH}$ range), they were stirred at $225 \mathrm{rpm}$ for $48 \mathrm{~h}$. The derivative method was used to plot the initial $\mathrm{pH}$ versus final $\mathrm{pH}$, in order to determine the PZC. Copper adsorption. $\mathrm{CuSO}_{4}$ solutions were prepared in 2, 4, 6, $810 \mathrm{mg} / \mathrm{L}$ concentrations; $0.1 \mathrm{~g}$ of pineapple biomass was added adjusting the $\mathrm{pH}$ to 5 . The solutions had a contact time of 0 to $24 \mathrm{~h}$.

Results: The pineapple peel had a 5.0 point of zero charge (PZC) value, which indicates that $\mathrm{pH}$ values higher than the PZC are required to obtain an adsorbent with a negatively charged surface and favor the copper adsorption. A 50\% copper removal was obtained in all concentrations after a $1 \mathrm{~h}$ contact time.

Limitations on study/implications: This research had no limitations.

Findings/conclusions: The point of zero charge is a reliable parameter that allows the adsorption process to take place and provides a greater certainty to the metal adsorption process. Meanwhile, pineapple peel can be used as an adsorbent material, consequently reducing its accumulation in open dumps.
\end{abstract}

Keywords: Pineapple peel, point of zero charge, copper adsorption.

\section{INTRODUCTION}

The climate, soil, temperature, rainfall, and altitude conditions of the humid tropics region of Mexico is suitable for pineapple (Ananas comosus L.) production. The states of Veracruz, Tabasco, Chiapas, and Campeche have the highest potential surface for its 
production. In Mexico, 44,182 ha of pineapple are currently grown; the total production is 1,041,161 t (SIAP, 2020). However, only $780 \mathrm{t}$ are used for fresh consumption or to make juice, jams, and preserves (Vélez-Izquierdo et al., 2020). This difference between production and consumption leads to an environmental and economic problem, as a consequence of the generation of a large volume of pineapple waste (including peel, crown, and pulp); all this inedible portion accounts for $41 \%$ of the fruit. Therefore, looking for alternative uses for this waste - based on effective techniques that can contribute to its reduction - is necessary.

Fruit peels - particularly from citrus fruits - have been studied as pollutant adsorbents (Romero, 2018; Pathak et al., 2016). They have high metal adsorption capacity, as a result of their pectin content. Pectin contains carboxylic groups, which in its anionic form attracts cationic species such as metals (García Villegas et al., 2011).

The $\mathrm{CaCl}_{2}$-modified orange peel can adsorb $36.1 \mathrm{mg} / \mathrm{g}$ of $\mathrm{Cu}$ (II) at a $\mathrm{pH}$ of 4.86 (Villanueva, 2007); the peanut shell adsorbs $60 \% \mathrm{Cu}$ (II) ions at a $\mathrm{pH}$ of 3 (Tapia, 2018); the pomegranate peel had a maximum adsorption of $\mathrm{Cu}$ (II) at a pH of 5.6-5.8 (El-Ashtoukhy et al., 2008). The $\mathrm{pH}$ is a factor that must be taken into account in the adsorption process, as it can indicate the degree of ionization of the adsorbent surface and its interaction with the adsorbate. Based on the point of zero charge, the $\mathrm{pH}$ at which the adsorbent retains anions or cations and thus optimizes the removal process can be determined (Amaringo-Villa and Hormaza-Anaguano, 2013). Several studies have been made about the use of pineapple residues as metal and dye adsorbent (Urrego et al., 2018). Succinic anhydride-modified pineapple peel has a maximum adsorption capacity of $\mathrm{Cu}$ (II) ions of $27.68 \mathrm{mg} \mathrm{g}^{-1}$ at a $\mathrm{pH}$ of 5.4 (Hu et al., 2011). However, most of those studies do not describe the determination of the point of zero charge. Therefore, the objective of this study is to establish a parameter that enhances the adsorption process and establishes an improved adsorbent-adsorbate interaction.

\section{MATERIALS AND METHODS}

The peel was obtained from Cabezona pineapples (Ananas comosus L.) acquired at the municipal market of Cárdenas, Tabasco.

\section{Physical Modification of the Pineapple Peel}

Drying: the pineapple peel is washed with plenty of water, cut into small fractions of approximately $5 \mathrm{~cm}$, dried in the sun for 3 days, and dehydrated at $60^{\circ} \mathrm{C}$ for $5 \mathrm{~h}$ in a drying oven. Crushing and sieving: once the material is dry, it is crushed until a small particle is obtained, which is then sieved through a \#40 mesh (upper part) and a \#60 mesh (lower part).

\section{Chemical Modification of Pineapple Peel with $\mathbf{C a C l}_{2}$}

$10 \mathrm{~g}$ of the dry material are added to $250 \mathrm{~mL}$ of a $0.2 \mathrm{M} \mathrm{NaOH}$ solution; the mixture is stirred for 2 hours, then filtered and washed until the excess $\mathrm{NaOH}$ is eliminated. Afterwards, it is dried at $40^{\circ} \mathrm{C}$ for $2 \mathrm{~h}$. Once dry, it is added to $250 \mathrm{~mL}$ of a $0.2 \mathrm{M} \mathrm{CaCl}_{2}$ solution, adjusting the $\mathrm{pH}$ to 5 , and stirred at a steady $200 \mathrm{rpm}$ for $24 \mathrm{~h}$. It is filtered and washed with deionized water and dried at $60^{\circ} \mathrm{C}$ for $6 \mathrm{~h}$. 


\section{Determination of the Point of Zero Charge}

Six solutions were prepared in 100-mL Erlenmeyer flasks. Fifty $\mathrm{mL}$ of distilled water were added to each flask and their $\mathrm{pH}$ was adjusted with standard $\mathrm{NaOH}$ and $0.1 \mathrm{M} \mathrm{HCl}$ solutions, in a 3-8 pH range. Pineapple biomass $(0.5 \mathrm{~g})$ at room temperature was added to each solution and it was constantly stirred at $225 \mathrm{rpm}$ for $48 \mathrm{~h}$. At the end of this process, the $\mathrm{pH}$ value was measured. The initial $\mathrm{pH}$ versus the final $\mathrm{pH}$ was plotted and the PZC was determined by the derivative method. The $\mathrm{pH}$ readings were taken with a Hanna H198103 Checker pH meter.

\section{Adsorption Study}

Five $\mathrm{CuCl}_{2}$ solutions were prepared at different concentrations (2, 4, 6, 8 and $\left.10 \mathrm{mg} / \mathrm{L}\right)$. Adsorbent $(0.1 \mathrm{~g})$ was added to each solution and the $\mathrm{pH}$ was adjusted to 5 . The mixtures were placed in contact time for $24 \mathrm{~h}$. A sample was taken every hour and its $\mathrm{Cu}$ (II) removal percentage was determined, using the following equation:

$$
\% \text { Removal }=\frac{C o-C e q}{C o} \times 100 \%
$$

Where: $C o=$ initial concentration; $C e q=$ balanced concentration.

\section{Copper Identification by Scanning Electron Microscopy Coupled with Elemental Analysis}

It was carried out in a JEOL JSM 610 LA model Scanning Electron Microscope (SEMEDX).

\section{RESULTS AND DISGUSSION}

\section{Determination of the Point of Zero Charge (PZC)}

The PZC is defined as the $\mathrm{pH}$ value corresponding to a balance point of (external and internal) charges on the adsorbent material (Sposito, 1998). $\mathrm{pH}$ values higher than $\mathrm{PZC}$ indicate that the surface is negatively charged, while $\mathrm{pH}$ values lower than $\mathrm{PZC}$ mean that the surface is positively charged (Amaringo and Hormaza, 2013). The PZC corresponds to the point where the curve of the final $\mathrm{pH}$ - versus the initial $\mathrm{pH}$ - crosses the diagonal. Figure 1 shows the graph of the initial $\mathrm{pH}$ versus final $\mathrm{pH}$. The pineapple peel had a 5.0 $\mathrm{PCZ}$ value; therefore, $\mathrm{pH}$ values higher than $\mathrm{PZC}$ will favor uptake during the metal ions adsorption in aqueous media.

\section{Copper Adsorption}

In order to demonstrate the application of the point of zero charge in the adsorption process, the removal of different concentrations of $\mathrm{Cu}$ (II) from aqueous solutions with a contact time of $24 \mathrm{~h}$ was studied. The particle size, temperature, and stirring speed remained constant. Figure 2 shows the maximum adsorption reached during the study. During the first hour, a maximum percentage of 66 was reached for the concentration of 




Figure 1. Point of zero charge of pineapple peel.

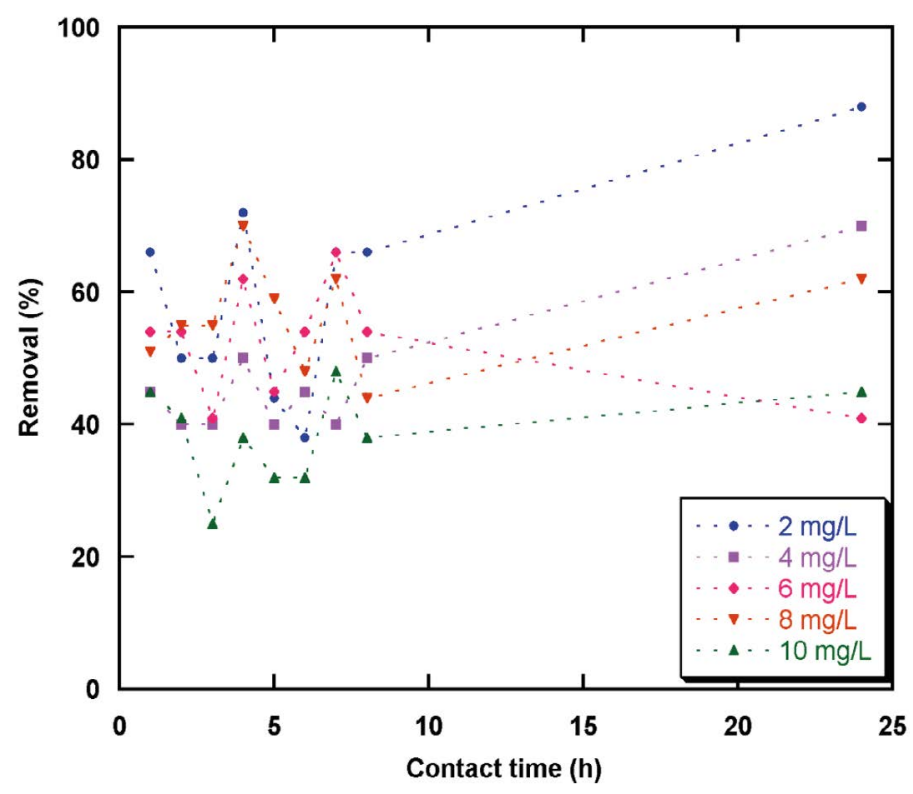

Figure 2. Removal percentage of $\mathrm{Cu}$ (II) at different contact times.

$2 \mathrm{mg} / \mathrm{L}$; from the $2^{\text {nd }}$ to the $7^{\text {th }}$ hour, there was a variation in the removal percentage, as a result of the balancing of the loads; at the $8^{\text {th }}$ hour, the removal percentage was similar to the 1 st hour. The maximum adsorption percentage is reached for all concentrations after 24 hours (Table 1).

Figure 3 shows the SEM image of the surface of the pineapple peel after it had adsorbed the copper ions - which can be seen as shiny particles lodged within the cavities of the adsorbent. The EDX elemental analysis confirms that its composition includes copper. 
Table 1. Maximum removal percentage.

\begin{tabular}{|c|c|c|c|c|c|}
\hline Time (h) & $\% \mathrm{R} 2 \mathrm{mg} \mathrm{L}^{-1}$ & $\% \mathrm{R} 4 \mathrm{mg} \mathrm{L}^{-1}$ & $\% \mathrm{R} 6 \mathrm{mg} \mathrm{L}^{-1}$ & $\% \mathrm{R} 8 \mathrm{mg} \mathrm{L}^{-1}$ & $\% \mathrm{R} 10 \mathrm{mg} \mathrm{L}^{-1}$ \\
\hline 1 & 66 & 45 & 54 & 51 & 45 \\
\hline 2 & 50 & 40 & 54 & 55 & 41 \\
\hline 3 & 50 & 10 & 41 & 55 & 25 \\
\hline 4 & 72 & 50 & 62 & 70 & 38 \\
\hline 5 & 44 & 40 & 45 & 59 & 32 \\
\hline 6 & 38 & 45 & 54 & 48 & 32 \\
\hline 7 & 66 & 40 & 66 & 62 & 48 \\
\hline 8 & 66 & 50 & 54 & 44 & 38 \\
\hline 24 & 88 & 70 & 41 & 62 & 45 \\
\hline
\end{tabular}

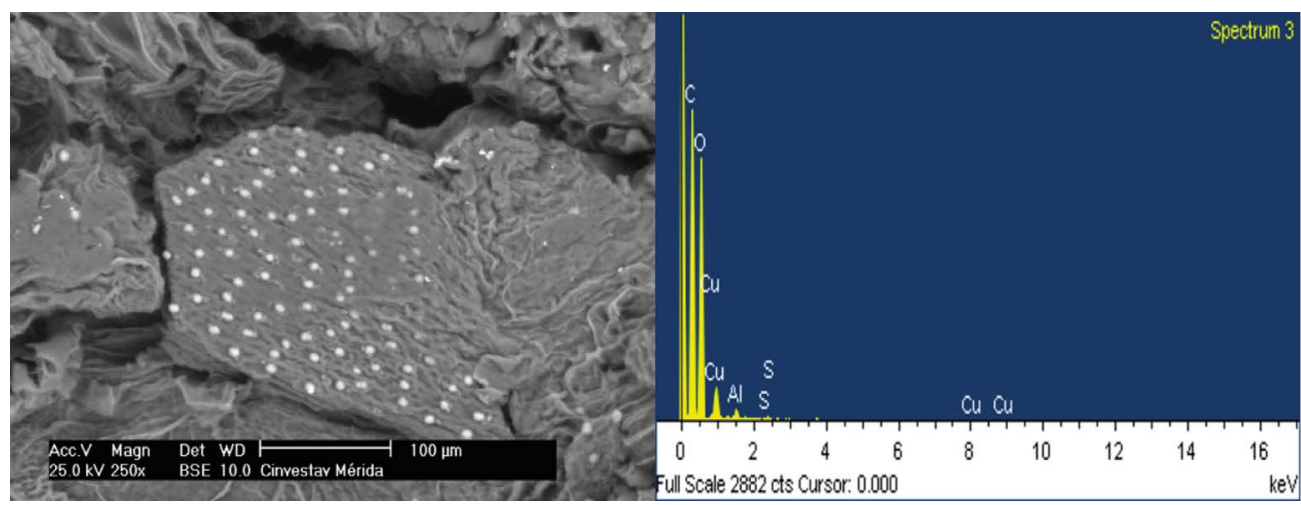

Figure 3. SEM image and elemental analysis of copper adsorption on pineapple peel.

\section{CONGLUSIONS}

Using the derivative method to determine the point of zero charge is a simple and fast procedure to establish the distribution of the charges on the surface of an adsorbent material. The $\mathrm{CaCl}_{2}$-modified pineapple peel can adsorb up to $50 \%$ of $\mathrm{Cu}$ (II) ions dispersed in water at a $\mathrm{pH}$ of 5 . The results of this study prove the potential of agricultural waste as metal adsorbents and consequently their capacity to avoid the negative environmental impact generated by its final disposal in open dumps.

\section{REFERENGES}

Amaringo Villa, F. A. \& Hormaza Anaguano, A. (2013). Determinación del punto de carga cero y punto isoeléctrico de dos residuos agrícolas y su aplicación en la remoción de colorantes. Revista de Investigación Agraria y Ambiental 4(2):27-36. https://hemeroteca.unad.edu.co/index.php/riaa/article/ view/982/963

El-Ashtoukhy, E.S.Z., Amin, N.K. \& Abdelwahab, O. (2008). Removal of lead (II) and copper (II) from aqueous solution using pomegranate peel as a new adsorbent. Desalination 223(1-3):162-173. https:// doi.org/10.1016/j.desal.2007.01.206

García Villegas, V.R., Yipmantin Ojeda, A.G., Guzmán Lezama, E. G., Pumachagua Huertas, R. \& Maldonado García H.J. (2011). Estudio de la cinética de bioadsorción de iones plomo en pectina reticulada proveniente de cáscara de cítricos. Revista de la Sociedad Química del Perú 77(3):173-181. https://doi.org/10.5377/torreon.v8i23.9534 
Hu, X., Zhao, M., Song, G. \& Huang, H. (2011). Modification of pineapple peel fibre with succinic anhydride for $\mathrm{Cu}^{2+}, \mathrm{Cd}^{2+}$ and $\mathrm{Pb}^{2+}$ removal from aqueous solutions. Environmental Technology 32(7): 739-746. https://doi.org/10.1080/09593330.2010.510853

Pathak, P.D., Mandavgane, S. A., \& Kulkarni, B.D. (2016). Characterizing fruit and vegetable peels as bioadsorbents. Current Science 110(11): 2114-2123. https://doi.org/10.18520/cs/v1 10/i1 1/2114-2123

Romero Cano, L.A., (2018). Preparación y caracterización de materiales adsorbentes a partir de cáscara de frutas para su uso en la remoción de metales y aplicación a procesos ambientales. Tesis profesional. Universidad de Granada. Centro de Investigación y Desarrollo Tecnológico en Electroquímica S.C. Santiago de Querétaro, Qro., México. https://cideteq.repositorioinstitucional.mx/jspui/ handle/1021/259

SIAP. 2020. Sistema de Información Agropecuaria y Pesquera. Cierre de la producción agrícola por estado. SIAP-SAGARPA. https://www.siap.gob.mx/agricultura-producción-anual

Sposito, G. (1998). On Points of Zero Charge. Environmental Science E Technology 32(19):2815-2819. https://doi. org/10.1021/es9802347

Tapia, P., Pavez, O., Garrido, N., Sepúlveda, B. (2018). Remoción de iones cobre y níquel con cáscara de maní. HOLOS 34(3): 57-69. https://doi.org/10.15628/holos.2018.7064

Urrego Durango, V.L., Vásquez-Noreña, P.A. \& Barrera Zapata, R. (2018). Uso de cáscara de piña como adsorbente de rojo 40 (típico de la industria alimentaria). Revista Colombiana de Investigaciones Agroindustriales 5(1): 87-95. http://dx.doi.org/10.23850/24220582.1362

Vélez-Izquierdo, A., Espinosa-García, J.A., Uresti-Gil, J., Jolalpa-Barrera, J.L., Rangel-Quintos, J., \& UrestiDuran, D. (2020). Estudio técnico-económico para identificar áreas con potencial para producir piña en el trópico húmedo de México. Revista Mexicana Ciencias Agrícolas 11(7): 1619-1632. https://doi. org/10.29312/remexca.v1 li7.2594

Villanueva, C., (2007). Biosorción de cobre (II) por biomasa pretratada de cáscara de Citrus sinesis (Naranja), Citrus limonium (limón) y Opuntia ficus (plameta de nopal). Tesis de licenciatura de Químico. Universidad Nacional del Mayor de San Marcos, Facultad de Química e Ingeniería Química, Lima-Perú. https:// hdl.handle.net/20.500.12672/2112 